\title{
Seed Cryopreservation of Some Medicinal Legumes
}

\author{
Alla B. Kholina and Nina M. Voronkova \\ Institute of Biology and Soil Science, Far Eastern Branch of Russian Academy of Sciences, 159 Prospect 100-letiya Vladivostoka, \\ Vladivostok 690022, Russia \\ Correspondence should be addressed to Alla B. Kholina, kholina@biosoil.ru
}

Received 8 July 2011; Accepted 30 November 2011

Academic Editor: Olivier Honnay

Copyright ( $) 2012$ A. B. Kholina and N. M. Voronkova. This is an open access article distributed under the Creative Commons Attribution License, which permits unrestricted use, distribution, and reproduction in any medium, provided the original work is properly cited.

\begin{abstract}
Seed survival after storage in liquid nitrogen $\left(-196^{\circ} \mathrm{C}\right)$ was examined in 12 wild medicinal legume species occurred Far East of Russia. Dry seeds of all species survived cryostorage without loss of viability. Initial germinability varied from 3 to $85 \%$. The stimulatory effect of cryogenic temperature on germination, with or without subsequent chemical scarification, was observed in all species studied with deep physical dormancy or heterogeneous levels of hardseededness. Frozen seeds demonstrated higher germination percentages (the percentage of germinated seeds) and germination rates (time for first seed to germinate $\left(\mathrm{T}_{0}\right)$ and time required (in days) to reach $50 \%$ of the final germination percentage $\left(\mathrm{T}_{50}\right)$ ) than the control ones. The anomalous seedlings were not observed after storage of seeds in liquid nitrogen. This study shows that cryostorage may be successfully applied for conservation of native species without detrimental effects on germination and growth.
\end{abstract}

\section{Introduction}

Fabaceae family is the one of the richest families of Russian Far-Eastern flora, and it includes a lot of valuable medicinal plants. The set of Far-Eastern legume species arouse particular interest due to pharmaceutical properties. Astragalus membranaceus (Fisch.) Bge., a herbaceous perennial, inhabits the western to northern part of China, Korea, and Japan. This herb is one of the important medicinal plants used as an adaptogenic in China, Korea, and Japan [1]; compounds from A. membranaceus roots may be utilized as immunostimulants, tonics, diuretics, antidiabetics, and sedatives [2]. Hedysarum austrokurilense (N.S. Pavlova) N.S. Pavlova and $H$. sachalinense B. Fedtsch. are perennial herb species endemic to the Sakhalin Island and South Kuril Islands [3]. The chemical components found in the plants of both related species include flavonoids, xanthones-mangiferin and isomangiferin, and polysaccharides many of them are of interest for traditional and modern medicines [4]. A lot of representatives of the genus Oxytropis have attracted attention thanks to the wide use in Tibetan and Mongolian medicine and also in folk medicines of Siberia and central Asia as the effective drugs [5]. The plants of some Oxytropis species are the richest in an alkaloid content [6], and alkaloid from O. ochrocephala has antitumor activity [7]; one can suppose that other Oxytropis species (O. chankaensis Jurtz., O. kamtschatica Hult., O. ochotensis Bunge, O. revoluta Ledeb., and O. retusa Matsum.) have also valuable bioactive substances. Sophora flavescens Soland., a perennial shrub, has been used in the herbal medicine for centuries in China, Japan, and Korea; the dried roots of S. flavescens have wellknown antibacterial, antiviral, antiprotozoal, anti-inflammatory, antitumor, and antipyretic effects ([8] and references herein, [9]). A perennial herb Trifolium lupinaster L. contains flavonoids and vitamins and has been used in Tibetan medicine against hepatitis [10]. Vicia amurensis Oett. is a perennial plant occurred in northern China, Japan, Korea, and Manchuria, contained flavonol glycosides [11], and used against tick-borne encephalitis and respiratory infections [12]. It was shown that alcohol extract of Vicia subrotunda seeds has antioxidant properties in experiments [13].

Nowadays, these legume species are attracting increasing attention of the modern pharmaceutical industry; however, natural resources of medicinal plants are limited, so it is reasonable to bring medicinal legumes under cultivation by seed conservation and reproduction. Cryopreservation (storage in liquid nitrogen $(\mathrm{LN})$ at $-196^{\circ} \mathrm{C}$ ) is the only currently available long-term storage technique that ensures 
TABLE 1: Seed collection site and ecological preference for 12 wild legume species studied.

\begin{tabular}{|c|c|c|}
\hline Species & Collection site & Distribution and ecological preference \\
\hline Astragalus membranaceus & $\begin{array}{l}\text { Primorye, Muraviev-Amurskii } \\
\text { Peninsula }\end{array}$ & $\begin{array}{l}\text { Widespread (Russia-Siberia, Far East; Mongolia, China, } \\
\text { Korea)/Forest meadows, dry meadows, steppe }\end{array}$ \\
\hline Hedysarum austro-kurilense & $\begin{array}{l}\text { Sakhalin, Makarov region, } \\
\text { Magutan mud volcano }\end{array}$ & $\begin{array}{l}\text { Endemic of North Sakhalin, South Kurils/Rocky hillsides, } \\
\text { coastal terraces }\end{array}$ \\
\hline H. sachalinense & $\begin{array}{l}\text { Sakhalin, Makarov region, } \\
\text { Tikhaia River, rocky hillsides }\end{array}$ & Endemic of Sakhalin/Coastal cliffs, rocky hillsides \\
\hline Oxytropis chankaensis & $\begin{array}{l}\text { Primorye, Khanka Lake, } \\
\text { Sosnovyi Island }\end{array}$ & $\begin{array}{l}\text { Endemic of Primorye, west coast of Khanka Lake/Sandy } \\
\text { lakeshores }\end{array}$ \\
\hline O. kamtschatica & $\begin{array}{l}\text { Kamchatka Peninsula, Central } \\
\text { Kamchatka, Kljuchevskaia Sopka } \\
\text { volcano }\end{array}$ & $\begin{array}{l}\text { Endemic of Far East of Russia (South Chukotka, Koryak Coast, } \\
\text { Kamchatka Peninsula)/Alpine tundra, rock debris, old lava } \\
\text { flows, shingle beach }\end{array}$ \\
\hline O. ochotensis & $\begin{array}{l}\text { Kamchatka Peninsula, Central } \\
\text { Kamchatka, Kljuchevskaia Sopka } \\
\text { volcano }\end{array}$ & $\begin{array}{l}\text { Regional (Russia-East Siberia, Far East (West Chukotka, } \\
\text { Kolyma, coast of the Okhotsk Sea, Kamchatka } \\
\text { Peninsula))/Alpine tundra, cliffs, rocky hillsides }\end{array}$ \\
\hline O. revoluta-1 & $\begin{array}{l}\text { Kamchatka Peninsula, Central } \\
\text { Kamchatka, Tolbachik volcano }\end{array}$ & $\begin{array}{l}\text { Regional (Russia-Far East (Koryak Coast, Kamchatka Peninsula, } \\
\text { North Kuril Islands); Aleutians)/Alpine tundra, stone, rock } \\
\text { debris, old lava flows, tephra, slag fields }\end{array}$ \\
\hline O. revoluta-2 & $\begin{array}{l}\text { Kamchatka Peninsula, Central } \\
\text { Kamchatka, Kljuchevskaia Sopka } \\
\text { volcano }\end{array}$ & As before \\
\hline O. retusa & $\begin{array}{l}\text { Kuril Islands, Paramushir Island, } \\
\text { Shelihov Bay, coastal rocky } \\
\text { hillside }\end{array}$ & Endemic of Kuril Islands/Coastal cliffs, rocky hillsides \\
\hline Sophora flavescens & $\begin{array}{l}\text { Primorye, Hasan region, Gamov } \\
\text { Peninsula }\end{array}$ & $\begin{array}{l}\text { Widespread (Russia-East Siberia, Far East; Mongolia, China, } \\
\text { Japan)/Forest meadows, dry meadows, river banks, xerophytic } \\
\text { scrub }\end{array}$ \\
\hline Trifolium lupinaster & $\begin{array}{l}\text { Primorye, Ternei region, Svetlaya } \\
\text { Bay, rock outcrops }\end{array}$ & $\begin{array}{l}\text { Widespread (Russia-Siberia, Far East; Mongolia, China, } \\
\text { Japan)/Open forest, meadows, shores }\end{array}$ \\
\hline Vicia amurensis & $\begin{array}{l}\text { Primorye, Muraviev-Amurskii } \\
\text { Peninsula, sea shores }\end{array}$ & $\begin{array}{l}\text { Widespread (Russia-East Siberia, Far East; China, } \\
\text { Japan/Hillsides, roadsides, old railway, xerophytic scrub, } \\
\text { meadows }\end{array}$ \\
\hline
\end{tabular}

safe conservation of genetic resources of valuable plant species [14-16]. Orthodox seeds of wild-growing legumes (moisture content from 5 to $12 \%$ ) are one of the most convenient systems available for prolonged storage of genetic information. Cryogenic storage has been successfully carried out in many orthodox seed species [15-20]; however in some species authors pointed out problems after cryopreservation, such as cotyledon breakage $[15,16,21]$, abnormal germination [1], or seed death by internal freezing injury [22]. In these cases, the role of seed characteristics, in particular seed size has been studied. The conventional regime of seed storage in seed banks at $5^{\circ} \mathrm{C}$ is not reliable, because low above-zero temperatures retard the loss of viability but fail to ensure its long-term preservation. The aim of the present study was to evaluate the effect of cryopreservation on the twelve Far-Eastern wild-growing legume species with different seed characteristics ( size and mass of seeds) for their ex situ conservation. The germination of wild legumes is often complicated by physical dormancy which may require scarification for germination, and thus combinations of dormancy-breaking procedures and exposure to $\mathrm{LN}$ have been tested to examine the interaction of cryopreservation and scarification. The results obtained suggest that seeds of species studied have the ability to tolerate cryostorage.

\section{Material and Methods}

2.1. Plant Material. The study was performed from 2002 to 2008. Mature seeds of twelve wild legume species were collected from wild plants growing in natural habitats from different regions of Far East of Russia (Table 1). Collected seeds stored in tightly closed bags in a laboratory at ambient temperature for 2-4 months until assays were carried out. Nomenclature, range, and distribution for species are according to the monograph on vascular plants of the Russian Far East [3]. For each species or population, seed mass was determined by weighting three samples of 100 seeds each; seed size, by measuring 25 seeds from each sample (Table 2). A batch of 50 seeds from each species was subjected to moisture determination by oven drying at $105^{\circ} \mathrm{C}$ for $24 \mathrm{~h}$, when the seeds had reached constant dry mass. Moisture content (MC) was obtained from 3 independent determinations and expressed as mean percentage of fresh weight (Table 2). For 3 species (Hedysarum austrokurilense, H. sachalinense, 


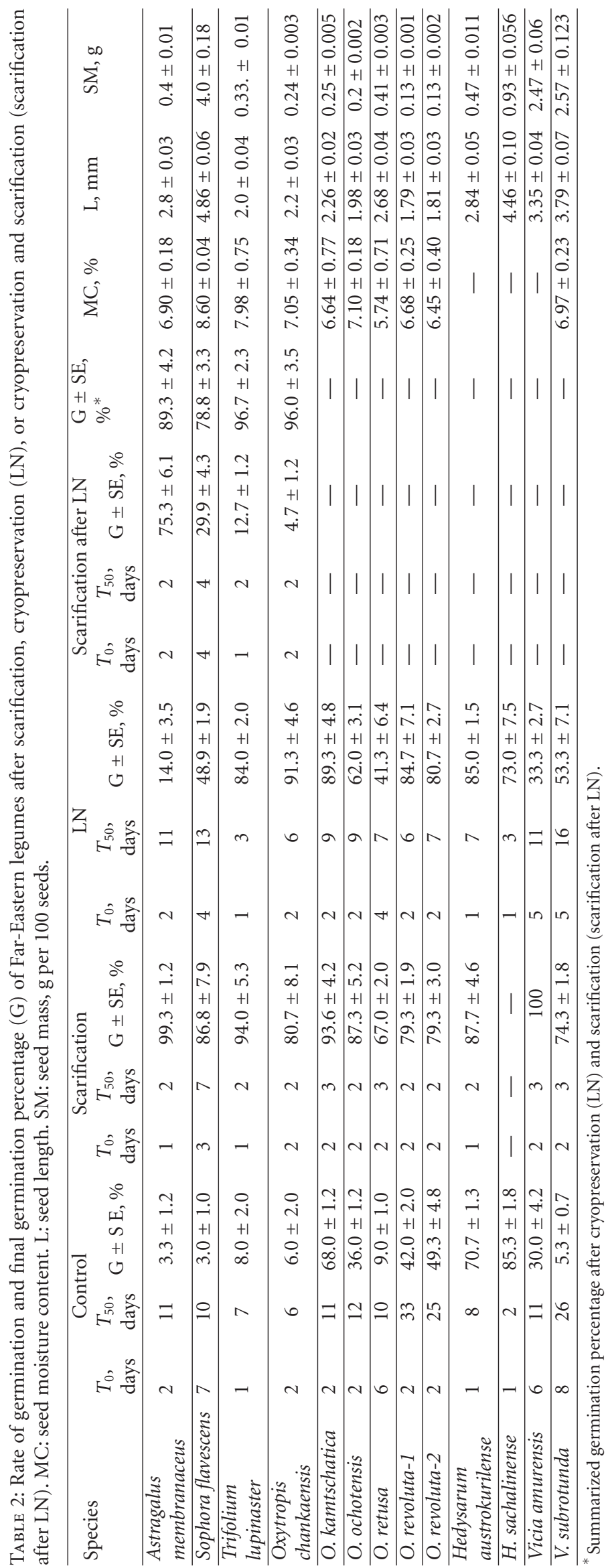


Vicia amurensis), MC was not determined due to small number of seeds. No desiccation procedures were carried out due to low level of seed moisture. Seeds of species tested contained 5.7-8.6\% moisture; seed mass ranged from 0.13 to $4.0 \mathrm{~g}$ per 100 seeds (Table 2 ).

2.2. Cryopreservation. The seeds in tightly closed aluminium foil bags were immersed directly into liquid nitrogen $\left(-196^{\circ} \mathrm{C}\right)$ and stored for 1 month, then warmed at room temperature $\left(21 \pm 3^{\circ} \mathrm{C}\right)$ for few hours before planting in germination dishes. Unfrozen seeds remained at room temperature.

2.3. Germination Test. For all treatments, the germination tests were carried out at $22-25^{\circ} \mathrm{C}$ under a $16 \mathrm{~h}$ light $/ 8 \mathrm{~h}$ night photoperiod. Three replicates of 50 seeds were placed on moist filter paper in Petri dishes and watered daily with tap water. The tests were monitored every day, and germinated seeds (radicle extension $\geq 2 \mathrm{~mm}$ ) were counted and removed. Incubation was continued until it was obvious that no further germination could occur. The first test was a control germination without any treatments. The second one presents germination after scarification. The water-impermeable legume seeds before plating in Petri dishes were scarified with a concentrated sulphuric acid: O. kamtschatica, O. ochotensis, O. revoluta, O. retusa-20 min; A. membranaceus, T. lupinaster, H. austrokurilense-30 min; S. flavescens$45 \mathrm{~min}$; V. amurensis, O. chankaensis-60 min; V. subrotunda-70 min. Then the seeds were washed in tap water and sown as described previously. The third attempt was germination after cryogenic storage. For most species, the major part of not-germinated after-cryopreservation seeds became soft and decayed. In four species-A. membranaceus, O. chankaensis, S. flavescens, T. lupinaster, the seeds, which failed to germinate during 2 months after cryopreservation, remained intact and undamaged. Then they were treated with a concentrated sulphuric acid, then washed in a tap water, and sown to evaluate a combined effect of cryopreservation and scarification. For each treatment, time of initial germination $\left(T_{0}\right)$ was determined, and final germination percentage (mean values \pm SE) and a number of days needed to reach $50 \%$ of the final germination percentage $\left(T_{50}\right)$ were calculated. To analyse the significance of differences between mean values, analysis of variance (ANOVA) was applied, as was the Tukey test for pairwise comparisons. The Tukey test was performed after arc-sine transformation at a significance level of $P<0.05$.

In two species- $H$. austrokurilense, $H$. sachalinense, the seedling emergence tests, like the germination tests, were conducted out at $22-25^{\circ} \mathrm{C}$ under $16 \mathrm{~h}$ light $/ 8 \mathrm{~h}$ night photoperiod, until the seedlings reached ca. $2-3 \mathrm{~cm}$ in height. Seedling vigor was measured by a shoot and root length on $15 \mathrm{~d}$ after sowing. Twenty five plantlets were measured in each sample.

In S. flavescens, plantlets from the control and cryopreserved seeds were transplanted to $1-\mathrm{L}$ pots with a soil to assess the quantitative traits (plant height, leaf size and number of the leaves, and root diameter) over three months (by measuring 30 plantlets from each sample). The data were analyzed using Student's $t$-test with significance at $P=0.05$.

\section{Results}

In control, the time of initial germination varied from 1 to 8 days, with both Hedysarum and T. lupinaster seeds germinating most rapidly. The germination of studied species seeds varied considerably, ranging from 3 to $85 \%$; this indicates the different levels of hardseededness. The seeds of six species (A. membranaceus, O. chankaensis, O. retusa, S. flavescens, T. lupinaster, $V$. subrotunda) showed very low germination percentages (less than 10\%). The germination rate also showed evident differences among species, with slowest rates in $V$. subrotunda and two populations of O. revoluta. The depth of hardseededness is species-specific and does not depend on seed size.

After scarification, germination was substantially higher and much faster as compared with control. It is indicative that seed dormancy was only of the physical type. For the most species $T_{0}$ and $T_{50}$ generally occurred at the same time (2-3 days after incubation), regardless of seed size. Seeds of A. membranaceus, O. chankaensis, S. flavescens, and T. lupinaster after scarification germinated about 30-40 days, though most of them germinated in first 10-14 days (Table 2). For the rest of the species, there were no any marked differences among them with respect to the germination rate; all seeds germinated rapidly for 7-12 days. Seed size and weight did not affect germination of scarified seeds apparently.

No damage was observed in control and scarified seeds. Cryopreservation was successful, and seeds of all species began to germinate after exposure to a cryogenic temperature. All tested species, except $H$. sachalinense and V. amurensis, exhibited a significant positive response to the 30-day exposure to LN when compared with control. Seed germination of $H$. sachalinense after cryostorage was high $(\geq 70 \%)$ and did not differ significantly from control $(P=0.203)$, while for $V$. amurensis one was rather low (Table 2) and also did not differ significantly from control $(P=0.527)$. Both populations of $O$. revoluta respond identically to the treatment though they differ in the initial levels of hardseededness. Cryostorage generally did not influence $T_{0}$, with an exception of seeds of $O$. retusa, $S$. flavescens, and both Vicia species, which germinated earlier than in control. For all species $T_{50}$ decreased to 3-16 days.

The germination rate of cryopreserved seeds was generally higher than for the unfrozen seeds, but lower than for scarified ones. No general trends between seed size and the ability of seed to survive to LN storage were observed. Nevertheless, a germination of the large seeds with high and moderate levels of hardseededness (S. flavescens, $V$. amurensis, $V$. subrotunda) did not exceed 50\% after LN exposure, while a germination of the small seeds with high levels of hardseededness (O. chankaensis, T. lupinaster) was above $80 \%$. For all species with small seed size (O. chankaensis, O. kamtschatica, O. ochotensis, O. revoluta, T. lupinaster) germination after cryostorage was very high (60-90\%). For these species and $H$. austrokurilense there was no significant differences 
between germination after scarification and LN treatment. A germination of A. membranaceus, O. chankaensis, S. flavescens, and T. lupinaster after freezing was enhanced by a scarification of the nongerminated seeds (Table 2). A. membranaceus and S. flavescens seeds reached significantly higher germination percentage than before scarification (from 14 to $89 \%$ and from 49 to $79 \%$, resp.).

Despite some variability in the seed germination among species studied, all seeds germinated after storage in LN developed into the normal seedlings with healthy shoot and root formation; no diseases were observed. The initial stages of seedling ontogenesis in the control and experimental samples of Hedysarum species went on synchronously. The seedlings coming from frozen and control seeds were morphologically and developmentally similar; that is, we could not detect differences in growth rate of shoot and root and in stem and root shape as well.

For S. flavescens, the formation of juvenile plants (an appearance of first two leaves) from the control seeds began earlier than from seeds stored in LN. There were no significant differences in the plant height, size and number of leaves, and root diameter between the plantlets derived from cryopreserved and control seeds during the entire period of culturing [23]. It is indicative of normal development of plantlets derived from the seeds treated by LN. Only slight increase of a root diameter was found in the 70-day-old seedlings from frozen seeds.

\section{Discussion}

The effect of an exposure to ultralow temperature (liquid nitrogen, $\mathrm{LN}$ ) on germination of the seeds was investigated in 12 wild medicinal legume species occurring Far East of Russia. The results show that the seeds of all investigated species can survive cryostorage.

There was no trend between seed size and survival of seeds after LN treatment. We observed higher germination percentages after cryostorage in the species with small seeds as compared to species with large seeds, which could be conditioned by presence of physical dormancy (hardseededness) in the tested species. The only exception was A. membranaceus seeds $(0.4 \pm 0.01 \mathrm{~g}$ per 100 seeds $)$ with the lowest germination after cryostorage, which evidently had a highest level of hardseededness, and scarification following LN treatment, allowed to reach high germination values (above 90\%).

The seeds of the studied species have a hard seed coat with a layer of macrosclereids (palisade-like cells with strongly lignified walls), typical for many wild Fabaceae species $[24,25]$, and most part of them is characterized by high and moderate levels of hardseededness (Table 2). A physical dormancy often occurs as a means of adaptation to the different habitats with the severe climatic conditions, and such seeds are highly resistant to unfavorable environmental factors $[26,27]$. It is low permeability of hard seed coat that may play some role in the cryotolerance of these seeds $[19,28]$. However, dormancy poses one of the main problems for work with wild species $[15,29]$. For the tested seeds of wild legumes, apparently, immersion in LN effects as a means of overcoming seed dormancy like scarification. It was reported that seed coat cracks, formed in the seeds impermeable to water during freezing, favoured a water uptake, and consequently germination was stimulated [30].

The final germination capacity of cryostored seeds differed significantly from nonstored ones for most species studied except $H$. sachalinense and $V$. amurensis. The stimulatory effects of $\mathrm{LN}$ exposure were revealed for other wild legumes with hard seeds $[1,15,21,31,32]$. Besides, after LN exposure, the seeds required less time to germinate than controls. In agreement with those results, it could be permitted to correlate them to the beneficial effects of low-temperature exposure, namely, stimulating germination and increasing germination rate. In addition, previous scarification or other dormancy-breaking treatment before germination seems not to be necessary for the most of these seeds. However, for seeds with deep physical dormancy LN is not effective scarifying agent, as it was shown for seeds of some Rubus species [33] and for seeds of A. membranaceus, S. flavescens, and V. amurensis in the present study. At the same time, for A. membranaceus and S. flavescens LN treatment, when combined with chemical scarification, favoured the germination resulting in considerable increase in germination percentage (Table 2). The similar action of combined treatment by LN and sulfuric acid has been observed in some orthodox legume seeds of Brazilian tropical species [32]. Necessity of scarification (mechanical or chemical scarification, heat treatment) combined with cryogenic storage to enhance the final germination percentage was shown for other species with hard seed coats $[28,29,34]$. The intensity of seed hardness varies among species and within individual species (e.g., in populations of $O$. revoluta), possibly due to the differences in their seed coat structure, physical, and chemical properties [25]. These differences might be reflected in the seeds response to $\mathrm{LN}$ treatment. As it is shown in previous studies, it is not possible to predict the behaviour of the seeds of a species after cryopreservation by their size or by taxonomic relatedness $[19,35]$. Therefore, it is important to continue screening different species for effective cryostorage and to investigate possible interactions with germination enhancement treatment.

In our experiments, cryopreserved seeds of Hedysarum species and S. flavescens developed into the normal seedlings and plants. Similar results were reported by Tikhonova [36] for 30 wild-growing plant species: plant growth and development was not adversely affected by cryopreservation. The normal growth of plants from the seeds treated by LN was shown for two Spanish endemic species [35] seven species of Orchidaceae $[37,38]$. It appeared that LN exposure only or combined treatments did not induce seed physical damage or abnormal seedling development for all species studied.

Thus, the obtained results have demonstrated that the seeds of the Far-Eastern medicinal legume species can be deep-frozen at $-196^{\circ} \mathrm{C}$ without loss of viability. Taking into account the tolerance to liquid nitrogen, cryogenic storage would be a suitable method for a long-term conservation of wild medicinal legumes. Additionally, the very small size of seeds of the most studied species results in an effective cryogenic procedure which is easy to operate. 


\section{Acknowledgments}

The work was supported by the Program of the Presidium of the Russian Academy of Sciences "Biological Diversity", the Program "Genetic Diversity of Natural Populations of Far East Plants" (Project no. 09-1-P23-06), and the Program of the Presidium of the Russian Academy of Sciences "Molecular and Cellular Biology” (Project no. 09-1-P22-03).

\section{References}

[1] T. Shibata, E. Sakai, and K. Shimomura, "Effect of rapid freezing and thawing on hard-seed breaking in Astragalus mongholicus Bunge (Leguminosae)," Journal of Plant Physiology, vol. 147, no. 1, pp. 127-131, 1995.

[2] S. Sinclair, "Chinese herbs: a clinical review of Astragalus, Ligusticum, and Schizandrae," Alternative Medicine Review, vol. 3, no. 5, pp. 338-344, 1998.

[3] N. S. Pavlova, "Family Fabaceae," in The Vascular Plants of the Soviet Far East, S. S. Kharkevich, Ed., vol. 4, pp. 191-339, Nauka, Leningrad, Russia, 1989.

[4] O. V. Neretina, A. S. Gromova, V. I. Lutsky, and A. A. Semenov, "Component composition of species of the genus Hedysarum (Fabaceae)," Rastitel'nye Resursy, vol. 40, no. 4, pp. 111-138, 2004.

[5] K. F. Blinova and E. I. Sakanyan, "Species of Oxytropis used in Tibetan medicine and their flavonoid composition," Rastitel'nye Resursy, vol. 22, no. 2, pp. 266-272, 1986.

[6] D. Batsuren, S. Tsetsegmaa, N. Batbayar et al., "Alkaloids of Oxytropis. I," Chemistry of Natural Compounds, vol. 28, no. 34, pp. 340-344, 1992.

[7] L. Long and Q. Li, "The effect of alkaloid from Oxytropis ochrocephala on growth inhibition and expression of PCNA and p53 in mice bearing $\mathrm{H}_{22}$ hepatocellular carcinoma," Yakugaku Zasshi, vol. 125, no. 8, pp. 665-670, 2005.

[8] J. D. Cha, M. R. Jeong, S. I. Jeong, and K. Y. Lee, "Antibacterial activity of sophoraflavanone $\mathrm{G}$ isolated from the roots of Sophora flavescens," Journal of Microbiology and Biotechnology, vol. 17, no. 5, pp. 858-864, 2007.

[9] S. Y. Ryu, S. U. Choi, S. K. Kim et al., "In vitro antitumour activity of flavonoids from Sophora flavescens," Phytotherapy Research, vol. 11, no. 1, pp. 51-53, 1997.

[10] G. A. Denisova, V. I. Dorofeev, and G. I. Kapranova, "Genus Trifolium L.," in Plant Resources of the USSR: Flowering Plants, Their Chemical Composition and Use, P. D. Sokolov, Ed., vol. 3 of Hydrangeaceae - Haloragaceae Families, pp. 181-191, Nauka, Leningrad, Russia, 1987.

[11] S. S. Kang, Y. S. Chang, and J. S. Kim, "Two new acylated flavonol glycosides from Vicia amurensis," Chemical and Pharmaceutical Bulletin, vol. 48, no. 8, pp. 1242-1245, 2000.

[12] P. L. Popov, "Plant species, using against virus infections of man and animals: regularities of the distribution in the phylogenetic classification system," Journal of Stress Physiology and Biochemistry, vol. 4, no. 3, pp. 17-64, 2008.

[13] O. V. Maksimov, P. G. Gorovoy, and G. N. Chumak, "The content of antioxidants in the seeds of some species of Primorie flora," Rastitel'nye Resursy, vol. 26, no. 4, pp. 487-498, 1990.

[14] F. Engelmann, "Plant cryopreservation: progress and prospects," In Vitro Cellular and Developmental Biology-Plant, vol. 40, no. 5, pp. 427-433, 2004.

[15] V. C. Pence, "Cryopreservation of seeds of Ohio native plants and related species," Seed Science and Technology, vol. 19, no. 2, pp. 235-251, 1991.
[16] P. C. Stanwood, "Cryopreservation of seed germplasm for genetic conservation," in Cryopreservation of Plant Cells and Organs, K. K. Kartha, Ed., pp. 199-226, CRC Press, Boca Raton, Fla, USA, 1985.

[17] P. Chmielarz, "Cryopreservation of dormant European ash (Fraxinus excelsior) orthodox seeds," Tree Physiology, vol. 29, no. 10, pp. 1279-1285, 2009.

[18] P. Chmielarz, "Cryopreservation of the non-dormant orthodox seeds of Ulmus glabra," Acta Biologica Hungarica, vol. 61, no. 2, pp. 224-233, 2010.

[19] D. H. Touchell and K. W. Dixon, "Cryopreservation of seed of Western Australian native species," Biodiversity and Conservation, vol. 2, no. 6, pp. 594-602, 1993.

[20] C. Walters, L. Wheeler, and P. C. Stanwood, "Longevity of cryogenically stored seeds," Cryobiology, vol. 48, no. 3, pp. 229244, 2004.

[21] H. W. Pritchard, K. R. Manger, and F. G. Prendergast, "Changes in Trifolium arvense seed quality following alternating temperature treatment using liquid nitrogen," Annals of Botany, vol. 62, no. 1, pp. 1-11, 1988.

[22] C. W. Vertucci, "Effect of cooling rate on seeds exposed to liquid nitrogen temperatures," Plant Physiology, vol. 90, no. 4, pp. 1478-1485, 1989.

[23] N. M. Voronkova and A. B. Kholina, "An influence of temperature factor and scarification on seed germination and growth of seedlings of Sophora flavescens Soland," Rastitel'nye Resursy, vol. 39, no. 1, pp. 43-49, 2003.

[24] J. M. Baskin, C. C. Baskin, and X. Li, "Taxonomy, anatomy and evolution of physical dormancy in seeds," Plant Species Biology, vol. 15, no. 2, pp. 139-152, 2000.

[25] K. M. Kelly, J. Van Staden, and W. E. Bell, "Seed coat structure and dormancy," Plant Growth Regulation, vol. 11, no. 3, pp. 201-209, 1992.

[26] A. B. Kholina and N. M. Voronkova, "Conserving the gene pool of Far Eastern plants by means of seed cryopreservation," Biology Bulletin, vol. 35, no. 3, pp. 262-269, 2008.

[27] N. M. Voronkova, A. B. Kholina, and V. P. Verkholat, "Plant biomorphology and seed germination in pioneer species of Kamchatka volcanoes," Biology Bulletin, vol. 35, no. 6, pp. 599605, 2008.

[28] P. Chmielarz, "Sensitivity of Tilia cordata seeds to dehydration and temperature of liquid nitrogen," Dendrobiology, vol. 47, pp. 71-77, 2002.

[29] S. Gonçalves, L. Fernandes, F. Pérez-García, M. E. GonzálezBenito, and A. Romano, "Germination requirements and cryopreservation tolerance of seeds of the endangered species Tuberaria major," Seed Science and Technology, vol. 37, no. 2, pp. 480-484, 2009.

[30] A. N. Salomao, "Effects of liquid nitrogen storage on Zizyphus joazeiro seeds," Cryo-Letters, vol. 16, no. 2, pp. 85-90, 1995.

[31] F. Pérez-García, "Effect of cryopreservation, gibberellic acid and mechanical scarification on the seed germination of eight endemic species from the Canary Islands," Seed Science and Technology, vol. 36, no. 1, pp. 237-242, 2008.

[32] A. N. Salomão, “Tropical seed species' responses to liquid nitrogen exposure," Brasilian Journal of Plant Physiology, vol. 14, no. 2, pp. 133-138, 2002.

[33] D. N. Peacock and K. E. Hummer, "Pregermination studies with liquid nitrogen and sulfuric acid on several Rubus species," HortScience, vol. 31, no. 2, pp. 238-239, 1996.

[34] F. Pérez-García and M. E. González-Benito, "Seed cryopreservation of Halimium and Helianthemum species," Cryo-Letters, vol. 29, no. 4, pp. 271-276, 2008. 
[35] M. E. González-Benito, F. Fernández-Llorente, and F. PérezGarcia, "Interaction between cryopreservation, rewarming rate and seed humidification on the germination of two Spanish endemic species," Annals of Botany, vol. 82, no. 5, pp. 683$686,1998$.

[36] V. L. Tikhonova, "Long-term storage of seeds," Russian Journal of Plant Physiology, vol. 46, no. 3, pp. 400-408, 1999.

[37] T. V. Nikishina, A. S. Popov, G. L. Kolomeitseva, and B. N. Golovkin, "Effect of cryoconservation on seed germination of rare tropical orchids," Russian Journal of Plant Physiology, vol. 48, no. 6, pp. 810-815, 2001.

[38] A. S. Popov, E. V. Popova, T. V. Nikishina, and G. L. Kolomeytseva, "The development of juvenile plants of the hybrid orchid Bratonia after seed cryopreservation," Cryo-Letters, vol. 25, no. 3, pp. 205-212, 2004. 

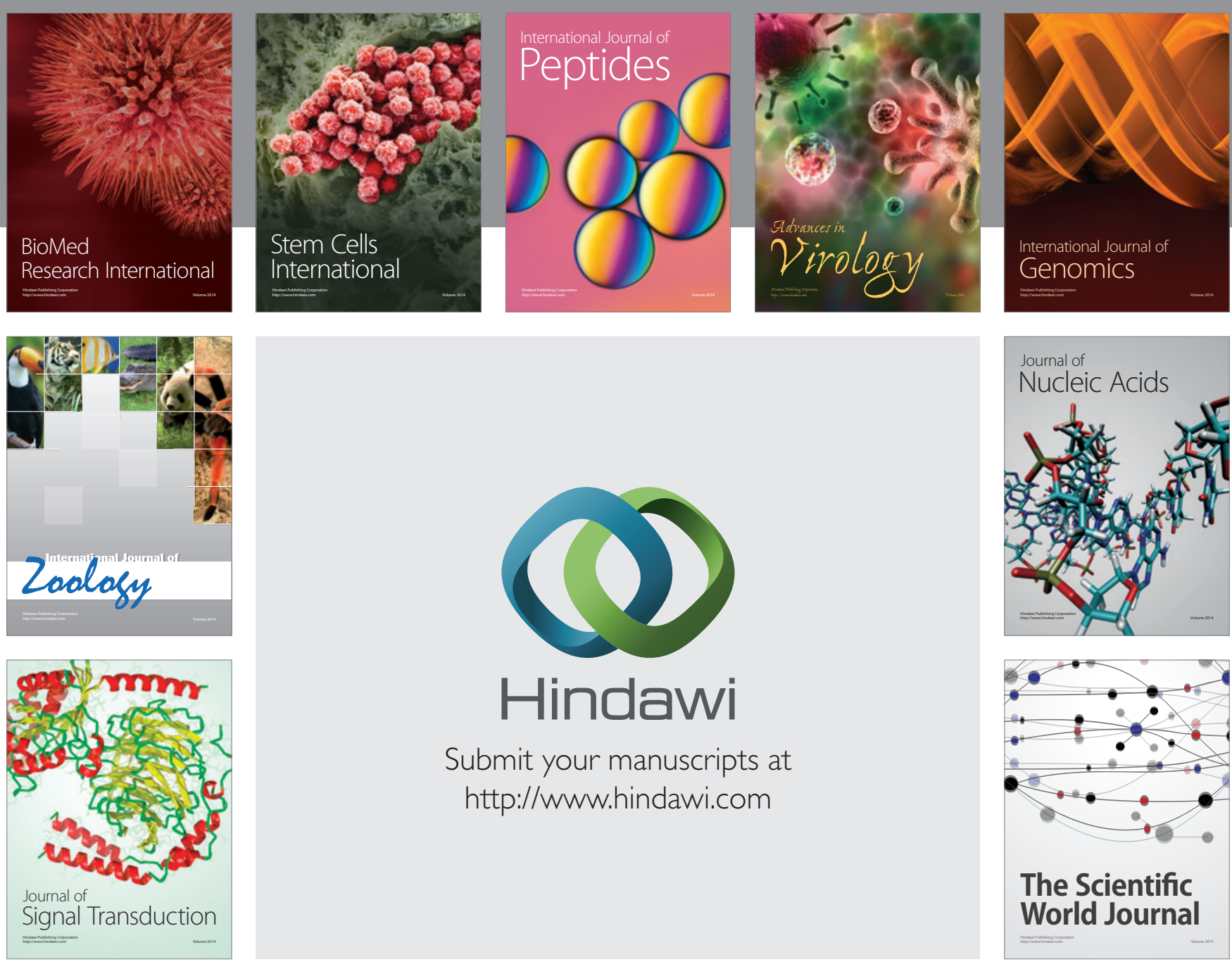

Submit your manuscripts at

http://www.hindawi.com
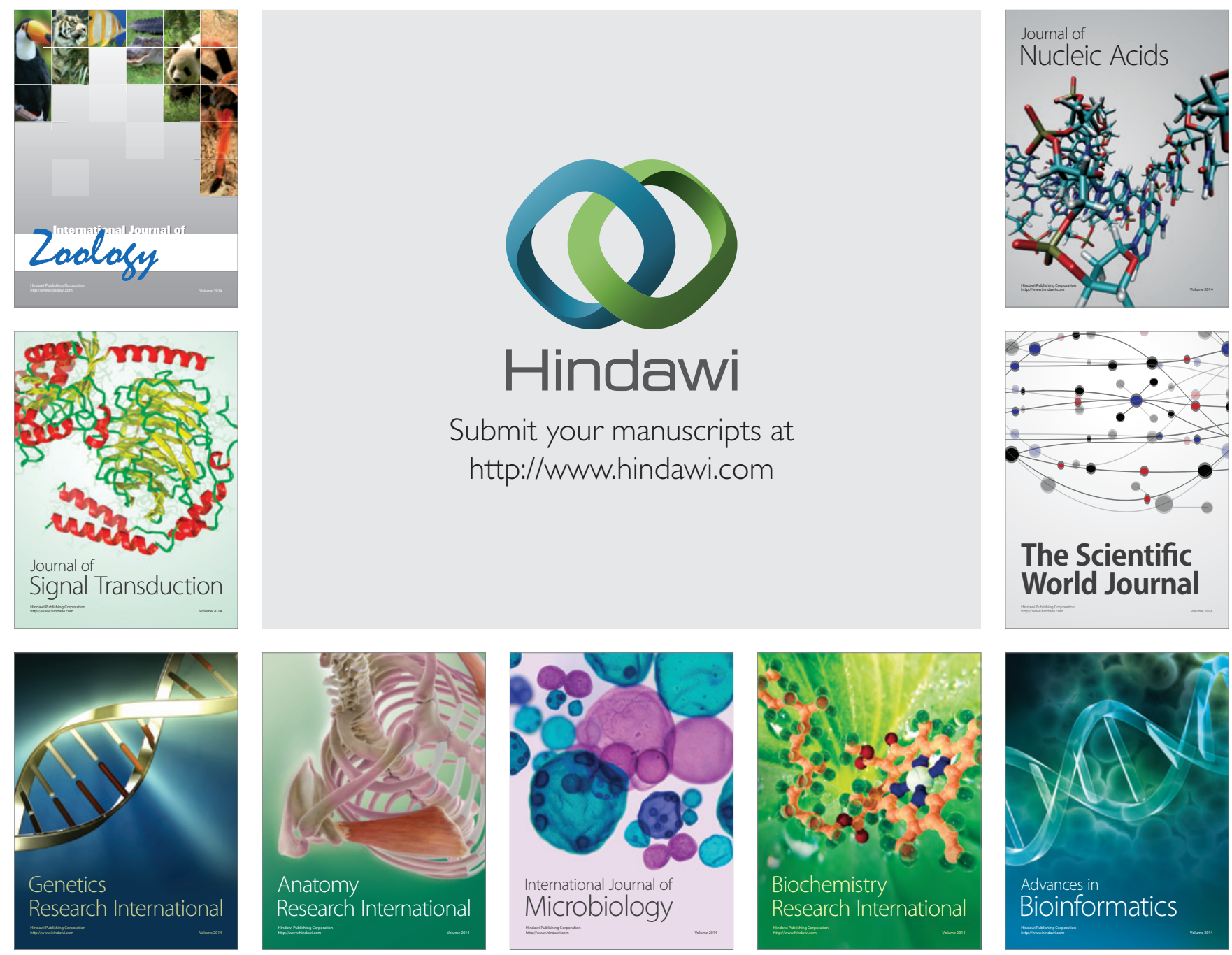

The Scientific World Journal
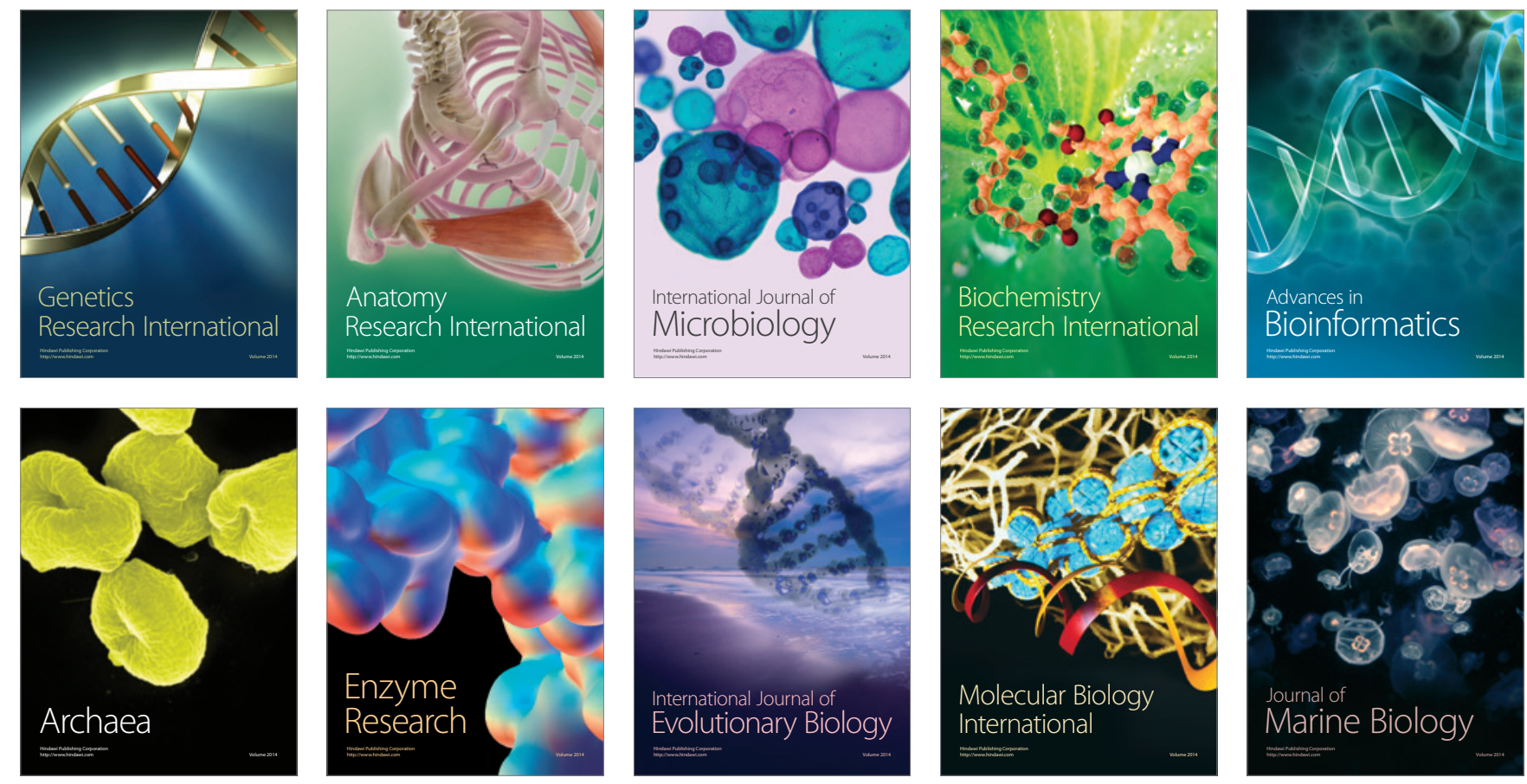